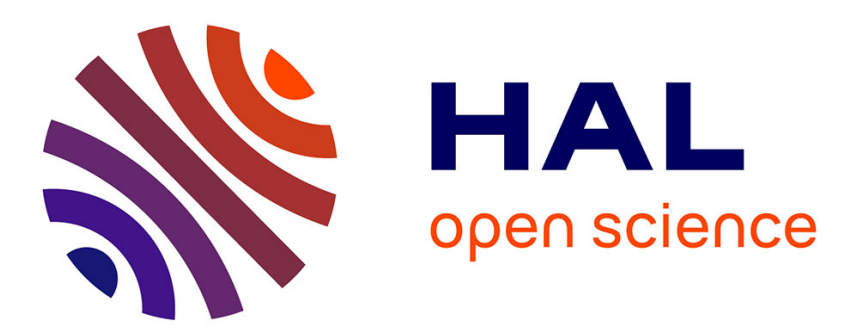

\title{
Introduction of Xenophobia and Citizenship: the Everyday Politics of Exclusion and Inclusion in Africa
}

Laurent Fourchard, Aurelia Segatti

\section{To cite this version:}

Laurent Fourchard, Aurelia Segatti. Introduction of Xenophobia and Citizenship: the Everyday Politics of Exclusion and Inclusion in Africa. Africa, 2015, Of Xenophobia and Citizenship. The Politics of Exclusion and Inclusion in Africa, 85 (1), pp.2-12. 10.1017/S0001972014000746 . halshs01251641

\section{HAL Id: halshs-01251641 \\ https://shs.hal.science/halshs-01251641}

Submitted on 27 Nov 2019

HAL is a multi-disciplinary open access archive for the deposit and dissemination of scientific research documents, whether they are published or not. The documents may come from teaching and research institutions in France or abroad, or from public or private research centers.
L'archive ouverte pluridisciplinaire HAL, est destinée au dépôt et à la diffusion de documents scientifiques de niveau recherche, publiés ou non, émanant des établissements d'enseignement et de recherche français ou étrangers, des laboratoires publics ou privés. 


\title{
INTRODUCTION OF XENOPHOBIA AND CITIZENSHIP: THE EVERYDAY POLITICS OF EXCLUSION AND INCLUSION IN AFRICA
}

\author{
Laurent Fourchard and Aurelia Segatti
}

\begin{abstract}
If you go to Alexandra (Johannesburg), to Sunnyside (Pretoria) ... everywhere, spaza shops, hair salons, everything has been taken over by foreign nationals ... They displace South Africans by making them not competitive. (Major Kobese, Director of Policy Support in the Office of the Director General, Department of Home Affairs, South Africa, cited by C. van der Westhuizen in Cape Times, 6 September 2011, p. 11)
\end{abstract}

Recent literature on the continent has focused attention on the increasing number of forms of belonging using different labels: autochthony, nativism, indigeneity, ethnicity, and in some cases xenophobia. The latter term generally refers to discourses and practices that are discriminatory towards foreign nationals, but Wimmer (1997) also sheds light on the existence of deeper political struggles for the collective goods of the state and the building of structures of legitimacy in accessing those goods. In many instances, those structures are based on collective identities and real or fantasized notions of national community (Wimmer 1997: 32). In the African contexts, decolonization struggles have specifically shaped the type of nation-building enterprises that have emerged in the postcolonial period (Chipkin 2007). Taking into consideration both this broader theoretical dimension and the specific historical trajectories of nationalist discourses in the African contexts, our understanding of xenophobia as discussed in this issue consists of the systematic situated (in one institution) or cross-cutting construction that sees strangers as a threat to society, justifying their exclusion and, at times, their suppression. In many instances, the term 'strangers' does not refer only to foreign nationals but can be used to describe strangers to one's community, locality or province, or one's ethnic or language group. In such instances, xenophobia takes on the features of autochthony, a much researched concept. However, while autochthony points to specific spatialized and essentialized structures of belonging to a community, a place or the soil (Geschiere and Nyamnjoh 2000), it does not necessarily encompass expectations against the state that are generally

\footnotetext{
LAURENT FOURCHARD is currently a senior researcher with the French Foundation of Political Science (FNSP) at the research institute 'Les Afriques dans le Monde' at Sciences Po Bordeaux, France. His research is located at the intersection of African history and African politics and his interests focus on youth, the regulation of violence and urban comparative research. Email: 1.fourchard@sciencespobordeaux.fr

Aurelia SEGATTI is currently a Labour Migration Expert with the International Labour Organization in Pretoria, South Africa. Prior to this, she was based at the African Centre for Migration \& Society, Faculty of Humanities, University of the Witwatersrand (Johannesburg) as Associate Professor, before becoming Research Manager at the Public Affairs Research Institute in the same university. Her research interests are migration policy, labour migration, xenophobic mobilization, economic indigenization and public administration. Email: aurelias@pari.org.za
} 
associated with the broader notion of xenophobia. Common to both is the production of an array of metaphors that invariably construe allochthons or strangers as threats to social order, to public health, and, in short, to the purity of the social body (Geschiere and Nyamnjoh 2000). The nuances of such metaphors are documented in this issue.

The analyses contained here make use of the vast literature devoted to the rhetoric and practice of autochthony, and the mobilization of multiple repertoires (ethnicity, territory, nationalism, indigeneity, ancestral land ownership, etc.) in the struggles for a redefinition of citizenship (Bayart et al. 2001; Meyer and Geschiere 1999; Kersting 2009; Cutolo 2008; 2010). Using the words 'autochthony' or 'indigeneity' is not without its problems, however. In several instances across the region, autochthony tends to reduce the reading of exclusion to an ontological sense of ownership over territory (whether real or fantasized). Discourses of indigeneity and autochthony are highly politicized, are subject to local and national particularities, and produce ambivalent, sometimes paradoxical, outcomes (Pelican 2009): they place the researcher at the heart of power struggles (Geschiere 2011: 212). Viewed from outside the continent, the current popularity of the term 'autochthony' in Africa includes an analytical bias; despite efforts to analyse autochthony within the process of globalization and to bridge the gap between Africa and the global North (Geschiere 2009), there is a risk of considering the continent as more prone to manifestations of belonging of a particular type, divorced from wider historical trends. That is, there is a danger of seeing the continent as one dominated by 'ethnic' and 'first-comer' claims rooted in the past, whereas other regions, mainly the West, are viewed as being dominated by nationalism, 'non-ethnic' or citizenship claims that are associated with territory through place of birth and/or residence (Zenker 2011). Our conceptual position is therefore to consider autochthony, nativism and indigeneity as local concepts used by actors in situations of xenophobia. In using 'xenophobia' as a generic key word, our intention has been to problematize the multiple meanings of these various ideas associated with it, but also to try to look beyond current mobilizations - or between them, in the interstices - in order to identify and characterize their specificities.

Several African countries offer an ideal lens through which to take these analyses further, as they combine, on the one hand, a variety of xenophobic mobilization and counter-mobilization histories and, on the other, a set of common features: colonially crafted ethnic divides in diverse societies, increasingly acute inequalities, strong demographic growth and rapid and jobless urbanization. This issue proposes a theoretically innovative, diverse, and empirically informed journey, shedding renewed light on concurrent processes associated with the redefinition of postcolonial citizenships: the exclusion of, mobilization against, and violent suppression of outsiders, but also their inclusion, and the multiple forms taken by subversion and resistance to exclusion. Drawing on extensive empirical research undertaken over the past three years across four countries (Democratic Republic of Congo, Kenya, Nigeria and South Africa), the analyses presented here do not assume that there is a unified meaning of xenophobia, but rather proceed with a careful, historically sensitive examination of apparently analogous dynamics and a questioning of their similarities and differences. 


\section{HISTORICIZING XENOPHOBIC ENVIRONMENTS}

Our first task was to historicize the different repertoires of belonging and exclusion that we came across. The Africanist literature on autochthony, for instance, has focused on two main historical moments. Firstly, autochthony has been studied as an outcome and a driver of the formation of colonial and postcolonial states; this dramatically shaped the categories of citizens and subjects, of 'firstcomers' and 'late-comers' (Bayart et al. 2001; Jackson 2006; Kuba and Lentz 2006; Mamdani 2002), and emphasized the specific type of nationalism and exclusion that liberation struggles and their rhetoric have given rise to in post-liberation periods (Chipkin 2007). The second historical moment that was marked by an upsurge of autochthony discourses and mobilizations is that of the 'global conjuncture of belonging' described by Geschiere (2009). In Africa, this expression has been associated especially with the democratization and decentralization processes of the 1990s that had the paradoxical effect of triggering an obsession with belonging. For some authors, while the promotion of national citizenship and the idea of 'nation building' had dominated the 1970s and 1980s, the following two decades - the 1990s and 2000s - represented a radical break with the former period (Geschiere and Nyamnjoh 2000: 425). Others saw a historical continuity running through the post-independence and nationalist periods, as, for instance, in Nigeria and Côte d'Ivoire (Akinyele 2009; Anthony 2002; Chauveau 2000; Fourchard 2009; Marshall-Fratani 2006).

Our intention in selecting the four countries of Democratic Republic of Congo (DRC), Kenya, Nigeria and South Africa is not to try to build forced similarities or to homogenize a situation that would be unique to the continent, but instead to pinpoint singularities and contingencies in the making of xenophobic practices. Comparative analysis highlights differences instead of reducing their importance (Bayart 2008). This is obvious from a very brief survey of contemporary xenophobic practices, rooted in colonial and national history, and shaped by the position of outsiders (whether domestic or international migrants) in the political economy of host societies, by different institutional arrangements, heterogeneous discriminatory legal cultures, and unequal openness to local citizenship. Key to the performance of exclusion is the naturalization of language categories intended to differentiate and legitimize differentiation. This reveals the power of designation and the capacity to assign specific identities or stigmas to groups or individuals (Noiriel 2007).

In Nigeria, the categories 'indigenes' and 'non-indigenes', institutionalized by the Federal State, not only are poorly contested by most citizens, but in most instances their legitimacy is internalized (Fourchard in this issue). Indigeneity has progressively acquired a political centrality, on the basis of which many differences and forms of exclusion have been manufactured. Nigerian political leaders were inspired by the legacy of Indirect Rule - which shaped and dramatically increased differences between natives and non-natives - and by the ideology of 1950s and 1960s regionalism - which favoured citizens of one region over the other two. Eventually, they formalized a form of indigeneity that granted rights and privileges to groups designated as indigenes in the 1970s. This policy led to discrimination against those labelled as non-indigenes as well as numerous violent conflicts between indigenes and non-indigenes; these conflicts were often shaped by the politics of defining who was the 'true' indigene of a specific place 
(Osaghae 1991; Adebanwi 2009; Higazi 2007). As in Nigeria, the word 'indigenous' is preferred in Kenya to the word 'autochthon', which is not used commonly. Indigenous land claims crystallized around the deployment of majimboism, which is understood by many to imply the forced expulsion of non-indigenous peoples from the Rift Valley and the restoration of ancestral lands to the native Kalenjin and Maasai communities (Boas and Dunn 2013: 56). But in the past two decades, other Kenyan communities have felt increasingly frustrated and indigenous claims to the land have recently appeared as a vindicatory strategy against intruders thought to have voted for the governing party and/or as a form of historical revenge by groups who were perceived to be marginalized by the state (Lonsdale 2008: 310). In the DRC, similar categories, called in French 'originaires' and 'non-originaires', and overlapping with the notion of 'sons of the soil' as identified by Jackson (2006), constitute the backbone of a civil registration system strictly based on territorial origin. Yet, these categories enjoy only intermittent recognition by state and non-state actors across the territory and are inconsistently used to determine access to public services or patronage networks. While they are used as a systematic redistribution system to balance all regional origins in the capital city of Kinshasa, in Katanga they are used as binaries to exclude Kasaians and to benefit South Katangese (Vinckel in this issue). Interestingly, the all-encompassing term 'expatriés', which used to designate mostly Western private sector immigrants in the 1960s and 1970s, alongside 'coopérants' (Westerners posted to Congo under cooperation agreements), is now used for all foreigners, including second- or third-generation West African immigrants to Congo. In South Africa, historical legacies seem to be rooted in apartheid-era processes of displacement (Nyamnjoh 2006: 56; Landau 2011: 5-7); these processes served the migrant labour system, which confined Black South Africans to the homelands and neighbouring countries in subaltern positions of surplus labour, the reproduction of which had to be subsidized by their place of origin (Burawoy 1976; Arrighi et al. 2010). Stigmatization of and violence against non-nationals in the post-apartheid period then emerge as the outcomes of a triple legacy: the continued, albeit transformed, use of migrants as cheap, disposable labour in a context of structural unemployment in which waged labour has come to be strongly identified with post-apartheid citizenship (Barchiesi 2011; Jinnah and Segatti 2013); the racial and social stereotyping of migrants by township dwellers rooted in the history of urban residency rights (Matsinhe 2011; Morris 1998; Nieftagodien 2011); and the indeterminacy of migrants' place in South African society produced by the South African public administration of home affairs through a corrupt and chaotic system of permits and a massive deportation policy regulating the presence of foreigners by removing them (Wa Kabwe-Segatti 2008). Thus, while overtly xenophobic terms have been in use over the past two decades, and reserved mostly for African immigrants, Monson (this issue) illustrates how the polarization between insiders and outsiders, long-term residents and newcomers, first-generation squatters and the newly settled, predates the national/non-national distinction, has influenced it very strongly in some localities, and constitutes an often poorly understood blueprint on which post-apartheid immigration is superimposed. 


\section{MANUFACTURING DIFFERENCE}

All these related terms clearly indicate that processes of exclusion or inclusion are closely intertwined. Geschiere (2011:212) rightly insists on the necessity of analysing the tension between inclusivist and exclusivist tendencies, but a quick look at the literature indicates that the attention paid to exclusionary discourses and practices that haunt the politics of belonging throughout the continent is not always balanced by an interest in countervailing discourses and practices (reconciliation, diffusing ethnic oppositions, everyday conviviality, etc.) (see, however, Page et al. 2010). In addition, while studies abound on processes of exclusion leading to violence and conflicts, much less has been written on the multiple tactics used by groups and individuals to deflect and escape discrimination. What therefore binds the works presented here and constitutes the originality of the issue is its emphasis on the everyday manufacture of difference and commonality (such as techniques used, repertoires mobilized and historical antecedents). The articles all document the sociology of authorities that claim to have legitimacy over the production of difference within a specific space; their target groups or individuals; and whether the 'excluded' define themselves as such and how they may accept, refuse or defuse the 'difference' ascribed to them.

All the articles are based on ethnographic research developed in four countries that have all gone through specific types of exclusionary violence over the past two decades: the DRC, Kenya, Nigeria and South Africa. Yet, unlike studies of the national contexts of conflicts over land ownership (Chauveau 2000; Kuba and Lentz 2006; Lund 1998; Lund and Boone 2013) or state attempts at imposing political hegemony (Banégas 2006; 2010; Boas 2009; Marshall-Fratani 2006), the articles here focus on local and urban scales, since xenophobic practices also rely on struggles over local political leadership, claims over localized resources, and competing definitions of belonging to a certain territory. The issue focuses on the local as the primary scale for the manifestation and performance of exclusionary practices or the materialization of alternatives to them. The issue does two things in particular. Firstly, it offers multiple, fine-grained explorations of these urban configurations of autochthony claims, mundane practices of xenophobia and very localized outbreaks of deadly xenophobic violence. If the literature on vigilante groups has documented the ways in which the performance of violence shapes insider/outsider boundaries (Pratten and Sen 2007), vigilante groups are just one among many different competing authorities. This issue hones in on the manner in which everyday practices and episodes of extreme violence reshape the making of authority, the self-definition of groups making claims to ownership over resources (Adunbi 2013; Hilgers 2011), and the boundaries of citizenship (Geschiere and Nyamnjoh 2000).

Another important yet overlooked dimension is that of the intersection between class differentiation, economic indigenization and the politics of belonging. Very little attention has been devoted to emerging class differences hiding underneath xenophobic statements. While it is beyond the scope of this introduction to provide a full account of the literature on economic indigenization in Africa (see Segatti in this issue), suffice it to say here that it has essentially focused on the economic impact of post-independence nationalization processes and the ways in which trade has been the reserve of nationals and affirmative action programmes; it has hardly ever analysed the discursive patterns and identity dynamics 
produced by these processes. Even where studies of indigenization and autochthony have emphasized the role played by decentralization and liberalization processes (Cutolo 2008), most have tended to neglect the class dynamics that inform interactions between national discourses on citizenship, global economic models and economic realities. Only a few scholars have pointed to autochthony-based discourses and mobilizations as an expression of social differentiation, and as a way to re-politicize the social scene and the public space (von Holdt 2013) or as a refuge of the weak in their resistance to the new rich and the land-grabbers who seem to be outside the law (Lonsdale 2008: 311; Cutolo 2008: 9). An unveiling of class differentiation beyond usual xenophobic registers is therefore necessary: Noiriel recently showed that the most long-lasting trend in immigration discourses in modern France was that of discrimination against the poor (Noiriel 2007: 656). Too little is known in many African countries about how differentiation on the basis of insider/outsider boundaries triggers new (or renewed) mobilization patterns and political subjectivities and exacerbates class dynamics in postcolonial contexts of neoliberal governmentality. These are contexts of ailing economies with ultra-rapid class differentiation among the 'liberated' (Southern Africa) or 'democratized' (DRC, Kenya, Nigeria) masses whose political leadership has enriched itself exponentially while the poor and the lower middle classes have seen their income levels plummet. In the DRC, histories of dispossession under the colonial and Mobutuist eras continue to inform contemporary discourses. Since the advent of the Kabila regime, the reorganization of internal rents has marginalized former regime clients, tempting them to enter into alliances with subaltern classes in an attempt to reclaim the economy from foreign operators. In South Africa and Nigeria, the largest two economies on the continent, the indigenization of public goods has emerged very strongly as a polarizing dynamic. The rising, albeit paradoxical, importance of waged labour in a time of high unemployment together with post-apartheid social resources in the form of grants and housing have considerably tightened the boundaries of formal citizenship since 1994 (Mosselson 2010; Hayem 2013).

\section{STATE FORMATION AND REPERTOIRES OF INCLUSION}

The country studies highlight the prominence of national paths that therefore offer plural forms of governmentality of both exclusion and inclusion. Xenophobia emerges as something that is intricately linked to the reshaping of postcolonial citizenships, as well as to unresolved issues of symbolic and economic resource redistribution. In these processes of exclusion, state institutions have been found to play an instrumental role, whether by turning a blind eye to discrimination or by institutionalizing it. This calls for a systematic exploration of the role of state bureaucracies, and their decentralized avatars, in engineering and manufacturing difference - or in not doing so. We suggest two directions. First, following recent scholarship of African state bureaucracies and the actual working of the state from below in the governance of daily life (Blundo and Le Meur 2009; Chalfin 2010; Chipkin and Meny-Gibert 2012; Bierschenk and Olivier de Sardan 2014; Darbon 2001), we propose to look closely at the making of boundaries through 
the provision of public services to citizens and non-citizens, or to insiders and outsiders, in the contemporary period. As suggested by John Lonsdale:

it is not to guard against some existential global threat that Africans expel stranger neighbors from the local community. They rebel rather against the daily inequalities, the unpredictable inclusions and exclusions by which their states decide who is to gain from global linkages and who bear their local costs. (Lonsdale 2008: 311)

This is one last thread that this issue explores more specifically. Discrimination has been systematically institutionalized in Nigeria through federal and state bureaucracies; there are apparently few exceptions to this, one being Lagos state (Mustapha 2006; Akinyele 2014; Fourchard, this issue), another being Gombe state, which has a more efficient conflict management system as shown by Higazi and Lar in this issue. Other national contexts offer less visible forms of state discrimination. In Kenya, government programmes aimed at redressing forced evictions following electoral violence have resulted in an ethnic fragmentation of urban space. In South Africa, while the constitution guarantees fundamental rights, social and labour policies are increasingly restricted to nationals and locals (with the exception of recognized refugees). Interestingly, in the DRC, different arms of the state have different agendas, either favouring outsiders who generate material or symbolic rents or harassing and excluding them to favour local elites.

Secondly, there is a need to re-examine the state not only as an institution but also as a political arena, a discursive space and a process in which there are winners and losers (Boas and Dunn 2013: 33). The groups that claim to be autochthonous in each case are more a consequence of state-building practices than historically coherent groups with a common past (Boas and Dunn 2013: 123). Autochthony is frequently linked to the desire for order inherent in contemporary state making, which invariably relies on multiple manifestations of violence (Dunn 2009). Many claims 'to be rooted' or 'to belong' are political strategies that rely on the arbitrary patronage of the modern Kenyan state, colonial and postcolonial (Lonsdale 2008: 306). This is also clear in Nigeria, where the federal regime is said to be ethno-redistributive and where large parts of political life are organized around infra-national identities and patronage networks (Adebanwi and Obadare 2013). In the DRC, regional legacies, entrenched in civil registration and the new decentralization policy, continue to inform the distribution of patronage but are inconsistently mobilized - less so in large, cosmopolitan urban and trade areas, more so in ethnically polarized regions with mineral resources. In South Africa, the 2008 riots can be seen as a key moment in the history of South African statecraft, revealing the gestation of two social dynamics: the creation in official speeches and institutional practices of an amorphous group of outsiders identified as a hindrance to the well-being and hard-earned liberation of the South African people; and the set of discursive patterns, ethical norms and practices through which violent exclusion is made possible and performed (Landau 2011).

While our work primarily focuses on exclusion and its effect on citizenship, we have tried to devote equal attention to the practices and repertoires of inclusion, which is understood as a dialogical dynamic of resistance to xenophobia yet has been largely under-researched. This issue documents precisely how processes of exclusion based on religious, ethnic, national and local forms of belonging are 
contested, disputed, ignored or fought against by a number of actors. What the studies also reveal is a vast array of resistance mechanisms, counter-mobilizations and subversion techniques, as well as emerging subjectivities (among the youth, gangs, women) that have appeared in response to exclusionary dynamics. How exclusion or identity assignation is subverted, resisted or ignored is documented in the issue. In Ongata Rongai, in Kenya, the bold use of 'cosmo' is a new form of local yet global identity that transcends fragmentation (Landau in this issue); in Kinshasa's markets, foreign traders use passive resistance, strategies of invisibilization and micro-arrangements with their Congolese counterparts (Segatti); while in Kolwezi and Likasi, reconciliation from below is based on silence and avoidance as interactional norms of peaceful coexistence between former enemies (Vinckel). All of them call attention to processes of counter-mobilization, deliberate non-involvement or open contestation of xenophobic practices through political mobilization or local or trade sociability. They also show the fragility of informal arrangements and individual or collective reconciliation processes 'from below', especially in times of crisis. In Nigeria, the political machinery appears to be inclusive in some states, and the centrality of patronage helps sideline discrimination in access to public goods (Fourchard in this issue). In comparing Gombe and Bauchi states, Adam Higazi and Jimam Lar argue that, although there are complaints of marginalization among different non-indigene groups in both cases, Gombe state has developed a more inclusive system of government and local conflict management than that of Bauchi state. The manufacturing of difference itself generates new forms of political subjectivities in contexts of hypermobile cosmopolitan areas as one of the ways out of structural legacies of discrimination. While the papers themselves provide too little evidence to proffer categorical statements on the emergence of alternative forms of belonging, they are at least an indication that some African urban polities are active centres for the contestation of exclusive forms of citizenship.

\section{ACKNOWLEDGEMENTS}

This special issue draws on research funded by the French Agence Nationale de la Recherche (ANR), Social and Human Sciences Programme, through grant contract ANR-10-SUDS-009-02. The editors would like to thank French research unit 'Les Afriques dans le Monde' (LAM), Political Science Institute (Bordeaux), the French Institutes of South Africa and Nigeria, the African Centre for Migration \& Society, University of the Witwatersrand, the Centre for African Studies at the University of Cambridge for hosting the closing conference and Adam Higazi for coordinating it, the conference discussants, Wale Adebanwi, Richard Banégas, Emma Hunter, Peter Geschiere, David Pratten, Egodi Uchendu and Ruth Watson, as well as Africa's reviewers for their insightful comments.

\section{REFERENCES}

Adebanwi, W. (2009) 'Terror, territoriality and the struggle for indigeneity and citizenship in Northern Nigeria', Citizenship Studies 13 (4): 349-63. 
and E. Obadare (eds) (2013) Democracy and Prebendalism in Nigeria: critical interpretations. New York NY: Palgrave Macmillan.

Adunbi, O. (2013) 'Mythic oil: resources, belonging and the politics of claim making among the Ilaje Yoruba of Nigeria', Africa 83 (2): 293-313.

Akinyele, R. (2009) 'Contesting for space in an urban centre: the Omo Onile syndrome in Lagos' in F. Locatelli and P. Nugent (eds), African Cities: competing claims on urban space. Leiden: Brill.

- (2014) 'Lagos is our land: indigeneship associations and the protection of the rights of Lagosians since 1950', XenAfPol Conference, University of Cambridge, 16-18 December 2014.

Anthony, D. A. (2002) Poison and Medicine: ethnicity, power and violence in a Nigerian city, 1966-1986. Oxford: James Currey.

Arrighi, G., N. Aschoff and B. Scully (2010) 'Accumulation by dispossession and its limits: the Southern Africa paradigm revisited', Studies in Comparative International Development 45: 410-38.

Banégas, R. (2006) 'Côte d'Ivoire: patriotism, ethnonationalism and other African modes of self-writing', African Affairs 105 (421): 535-52.

_ (2010) 'La politique du "gbonhi". Mobilisations patriotiques, violence milicienne et carrières militantes en Côte d'Ivoire', Genèses 81 (December): 25-44.

Barchiesi, F. (2011) Precarious Liberation: workers, the state, and contested social citizenship in post-apartheid South Africa. Durban and New York NY: University of Kwazulu-Natal Press and State University of New York Press.

Bayart, J.-F. (2008) 'Comparer en France. Petit essai d'autobiographie disciplinaire', Politix 3 (83): 205-32.

, P. Geschiere and F. Nyamnjoh (2001) 'Autochtonie, démocratie, citoyenneté en Afrique', Critique internationale 10: 177-94.

Bierschenk, T. and J. P. Olivier de Sardan (eds) (2014) States at Work: dynamics of African bureaucracies. Leiden: Brill.

Blundo, G. and P. Y. Le Meur (eds) (2009) The Governance of Daily Life in Africa: ethnographic explorations of public and collective services. Leiden: Brill.

Boas, M. (2009) 'New nationalism and autochthony: tales of origin as political cleavage', Africa Spectrum 44 (1): 19-38.

- and K. Dunn (2013) Politics of Origin in Africa: autochthony, citizenship and conflict. London: Zed Books.

Burawoy, M. (1976) 'The functions and reproduction of migrant labor: comparative material from Southern Africa and the United States', American Journal of Sociology 81 (5): 1050-87.

Chalfin, B. (2010) Neoliberal Frontiers: an ethnography of sovereignty in West Africa. Chicago IL: University of Chicago Press.

Chauveau, J. P. (2000) 'Question foncière et construction nationale en Côte d'Ivoire', Politique Africaine 78: 94-125.

Chipkin, I. (2007) Do South Africans Exist? Nationalism, democracy and the identity of 'the people'. Johannesburg: Wits University Press.

— and S. Meny-Gibert (2012) 'Why the past matters', Journal of Public Administration 46 (1): 102-12.

Cutolo, A. (2008) 'Populations, citoyennetés et territoires: autochtonie et gouvernementalité en Afrique', Politique Africaine 112: 5-17.

— (2010) 'Modernity, autochthony and the Ivoirian nation: the end of a century in Côte d'Ivoire', Africa 40 (4): 527-52. 
Darbon, D. (2001) 'De l'introuvable à l'innommable: fonctionnaires et professionnels de l'action publique dans les Afriques', Autrepart 20: 27-42.

Dunn, K. C. (2009) 'Sons of the soil and contemporary state making: autochthony uncertainty and political violence in Africa', Third World Quarterly 30 (1): 113-27.

Fourchard, L. (2009) 'Dealing with "strangers": allocating urban space to migrants in Nigeria and French West Africa, end of the 19th century to 1960' in P. Nugent and F. Locatelli (eds), African Cities: competing claims on urban space. Leiden: Brill.

Geschiere, P. (2009) The Perils of Belonging: autochthony, citizenship, and exclusion in Africa and Europe. Chicago IL: University of Chicago Press.

(2011) 'Responses to Irène Bellier: misunderstanding of autochthony vis-à-vis the question of indigenous peoples', Social Anthropology 19 (2): 204-12.

and F. Nyamnjoh (2000) 'Capitalism and autochthony: the seesaw and mobility of belonging', Public Culture 12 (2): 423-52.

Hayem, J. (2013) 'From May 2008 to 2011: xenophobic violence and national subjectivity in South Africa', Journal of Southern African Studies 39 (1): 77-97.

Higazi, A. (2007) 'Violence urbaine et politique à Jos (Nigeria), de la période coloniale aux élections de 2007', Politique Africaine 106 (2): 69-91.

Hilgers, M. (2011) 'Autochthony as capital in a global age', Theory, Culture and Society 28 (1): 34-54.

Jackson, S. (2006) 'Sons of which soils? The language and politics of autochthony in Eastern D. R. Congo', African Studies Review 49 (2): 95-123.

Jinnah, Z. and A. Segatti (2013) 'Concept note. Work package 3: sectors. The political economy of migrant labour in South Africa: examining skills, wages, policies, and practices. Migrating for Work Research Consortium (MiWORC)'. Johannesburg: African Centre for Migration and Society (ACMS), Wits University.

Kersting, N. (2009) 'New nationalism and xenophobia in Africa: a new inclination?', Africa Spectrum 1: 7-18.

Kuba, R. and C. Lentz (eds) (2006) Land and the Politics of Belonging in West Africa. Leiden: Brill.

Landau, L. B. (ed.) (2011) Exorcising the Demons Within: xenophobia, violence, and statecraft in contemporary South Africa. Johannesburg: Wits Press.

Lonsdale, J. (2008) 'Soil, work, civilisation and citizenship in Kenya', Journal of Eastern African Studies 2 (2): 305-14.

Lund, C. (1998) Law, Power and Politics in Niger: land struggles and the rural code. Hamburg and New Brunswick NJ: Lit Verlag and Transaction Publishers. and C. Boone (2013) 'Introduction: land politics in Africa-constituting authority over territory, property and persons', Africa 83 (1): 1-13.

Mamdani, M. (2002) When Victims Become Killers: colonialism, nativism, and the genocide in Rwanda. Princeton NJ: Princeton University Press.

Marshall-Fratani, R. (2006) 'The war of "who is who": autochthony, nationalism, and citizenship in the Ivoirian Crisis', African Studies Review 49 (2): 9-43.

Matsinhe, M. (2011) 'Africa's fear of itself: the ideology of makwerekwere in South Africa', Third World Quarterly 32 (2): 295-313.

Meyer, B. and P. Geschiere (eds) (1999) Globalisation and Identity: dialectics of flow and closure. Oxford: Blackwell. 
Morris, A. (1998) "Our fellow Africans make our lives hell": the lives of Congolese and Nigerians living in Johannesburg', Ethnic and Racial Studies 21 (6): 1116-36.

Mosselson, A. (2010) "There is no difference between citizens and non-citizens anymore": violent xenophobia, citizenship and the politics of belonging in post-apartheid South Africa', Journal of Southern African Studies 36 (3): 641-55.

Mustapha, A. A. (2006) Ethnic Structure, Inequality and the Governance of the Public Sector in Nigeria. Democracy, Governance and Human Rights Programme paper no. 24. Geneva: United Nations Research Institute for Social Development.

Nieftagodien, N. (2011) 'Xenophobia's local genesis: historical constructions of insiders and the politics of exclusion in Alexandra township' in L. B. Landau (ed.), Exorcising the Demons Within: xenophobia, violence, and statecraft in contemporary South Africa. Johannesburg: Wits Press.

Noiriel, G. (2007) Immigration, antisémitisme et racisme en France (XIXème et XXème siècle). Discours publics, humiliations privées. Paris: Fayard.

Nyamnjoh, F. (2006) Insiders and Outsiders: citizenship and xenophobia in contemporary southern Africa. Dakar and London: CODESRIA and Zed Books.

Osaghae, E. E. (1991) 'Ethnic minorities and federalism in Nigeria', African Affairs 90 (359): 237-58.

Page, B., M. Evans and C. Mercer (2010) 'Revisiting the politics of belonging in Cameroon', Africa 80 (3): 345-70.

Pelican, M. (2009) 'Complexities of indigeneity and autochthony: an African example', American Ethnologist 36 (1): 52-65.

Pratten, D. and A. Sen (eds) (2007) Global Vigilantes. London: Hurst and Company.

von Holdt, K. (2013) 'South Africa: the transition to violent democracy', Review of African Political Economy 40 (138): 589-604.

Wa Kabwe-Segatti, A. (2008) 'Violences xénophobes en Afrique du Sud: retour sur un désastre annoncé', Politique Africaine 112: 99-118.

Wimmer, A. (1997) 'Explaining xenophobia and racism: a critical review of current research approaches', Ethnic and Racial Studies 20 (1): 17-41.

Zenker, O. (2011) 'Autochthony, ethnicity, indigeneity and nationalism: timehonouring and state-oriented modes of rooting individual-territory group triads in a globalising world', Critique of Anthropology 31 (1): 63-81. 